\title{
Dabigatran level monitoring prior to idarucizumab administration in patients requiring emergent cardiac surgery
}

\author{
Radoslaw Litwinowicz ${ }^{1}$ (D) J Janusz Konstanty-Kalandyk ${ }^{1,2} \cdot$ Tadeusz Goralczyk $^{3} \cdot$ Krzysztof Bartus $^{1,2} \cdot$ Piotr Mazur $^{1,2}$ (D)
}

Published online: 8 December 2017

(c) The Author(s) 2017. This article is an open access publication

To the Editor,

Non-vitamin-K antagonist oral anticoagulants (NOACs), including dabigatran (a direct factor IIa [FIIa] inhibitor) increasingly replace the vitamin $\mathrm{K}$ antagonists (VKAs) for favorable risk-benefit profile [1] and lower risk of major bleeding [2] in atrial fibrillation. NOACs also significantly reduce the risk of recurrent venous thromboembolism (VTE), and compared with VKAs present lower risk of bleeding in this group [3]. The use of NOACs increases in VTE prevention, even though in the setting of surgical emergency or life-theratening bleeding, the NOAC therapy may be dangerous [4].

In 2015, the FDA approved idarucizumab for dabigatran reversal in emergency situations [5]. Idarucizumab is a monoclonal antibody fragment that binds dabigatran with high affinity, and presents good clinical outcomes [5, 6]. Current European Heart Rhythm Association (EHRA) practical guidelines recommend idarucizumab for life-threatening bleeding, or prior to emergency surgery in dabigatran treated patients [7].

Clinical experience with idarucizumab in cardiac surgery is currently limited. In our institution, we managed several dabigatran-treated patients in emergency cardiosurgical setting [8]. In previous cases, the clinical decision to administer idarucizumab was made following emergency laboratory

Radoslaw Litwinowicz and Janusz Konstanty-Kalandyk are first authors of this manuscript and have contributed equally to the content of this paper.

Piotr Mazur

piotr.k.mazur@gmail.com

1 Department of Cardiovascular Surgery and Transplantology, The John Paul II Hospital, Kraków, Poland

2 Institute of Cardiology, Jagiellonian University Medical College, 80 Prądnicka St., Kraków 31-202, Poland

3 Central Laboratory, The John Paul II Hospital, Kraków, Poland assessment of baseline dabigatran level (both individuals required an open-heart surgery for acute aortic syndrome) [8]. However, in specific clinical scenarios, monitoring of dabigatran level may be challenging and potentially impede the decision to use the expensive idarucizumab preparation based just on uncertain dabigatran intake history, and exposing the patient to the risk of excessive (and potentially lethal) surgical bleeding, if dabigatran intake history is uncertain.

We report a case of a 63-years-old patient who received dabigatran for VTE and required emergency coronary artery bypass grafting (CABG) for an acute coronary syndrome (ACS) with coronary anatomy precluding percutaneous coronary intervention (PCI), in whom the preoperative dabigatran level measurement was futile because of interferences with other thrombin inhibitors.

\section{Case presentation}

A 63-years-old male patient with a history of stable coronary artery disease (CAD), previous myocardial infraction (MI), deep venous thrombosis, polycythemia vera and arterial hypertension was admitted to our Institution (tertiary cardiac care center) for the surgical management of a newonset ACS in form of ST-segment elevation MI. He received dabigatran due to VTE $(2 \times 150 \mathrm{mg} /$ day; last dose intake on the day of surgery) [3]. The patient was admitted to a local hospital due to severe chest pain. As soon as the ACS diagnosis was made, the coronary angiography was performed, showing a multi-vessel coronary disease with critical stenosis $(99 \%)$ of three arteries, and impending occlusion of the critically stenotic left main coronary artery (the right coronary artery was recessive). Because of the unfavorable anatomy, the patient was consulted online with the emergency Heart Team, started on unfractionated heparin (UFH) in continuous infusion, and transferred to our department for emergency CABG. 
The surgical Team was called in, and dabigatran level, thrombin time, reptilase time, activated partial thromboplastin time (APTT) and prothrombin time were measured on admission. His renal function was preserved (estimated glomerular filtration rate was $75 \mathrm{ml} / \mathrm{min}$ ).

Dabigatran plasma concentration was determined on the BCS-XP automated analyzer (Siemens Healthcare Diagnostics Products GmbH, Marburg, Germany), using the Hemoclot thrombin inhibitors (HTI) assay (Hyphen BioMed, Neuville-Sur-Oise, France). The assay based on modified diluted thrombin time was calibrated with the calibrators (Biophen ${ }^{\circledR}$ Dabigatran Calibrator Low) containing different concentrations of dabigatran $(0,56$ and $108 \mathrm{ng} / \mathrm{mL})$. A set of two levels control plasmas of dabigatran $\left(\right.$ Biophen $^{\circledR}$ Dabigatran Control Low) was used for the quality control of measurements. Reproducibility at dabigatran concentrations of 29 and $80 \mathrm{ng} / \mathrm{mL}$ were $12.7(\mathrm{n}=10)$ and $8.7 \%(\mathrm{n}=10)$, respectively.

Unfortunately, the measurement of dabigatran plasma concentration was non-diagnostic because of the continuous UFH infusion. Nevertheless, the laboratory test was repeated five times in different time intervals. All laboratory results are present in Table 1. In spite of the inability to measure the dabigatran concentration, the patient received $5 \mathrm{~g}$ of intravenous idarucizumab in two $50-\mathrm{ml}$ bolus infusions (each containing $2.5 \mathrm{~g}$ of idarucizumab, no more than $15 \mathrm{~min}$ apart, directly before the operation).

After idarucizumab administration, CABG in normothermic cardiopulmonary bypass (CPB) followed. The saphenous vein grafts were placed to marginal and diagonal coronary arteries, and the left internal mammary artery was grafted to the left anterior descending coronary artery, following the standardized procedures. CPB time was $97 \mathrm{~min}$, aortic cross clamp was $52 \mathrm{~min}$, the overall procedural time was $140 \mathrm{~min}$. Despite the scrupulous surgical hemostasis, the postoperative bleeding, according to the universal definition of perioperative bleeding in cardiac surgery, was severe [9]. The chest tube output was $840 \mathrm{ml}$ after $24 \mathrm{~h}$, and a total of two units of red blood cells, four units of platelets and eight units of fresh frozen plasma were administered in the first $24 \mathrm{~h}$ after the procedure.

During the postoperative course, the patient required antibiotics for postoperative pneumonia, diuretic treatment and intensive pulmonary rehabilitation. Antiplatelet regimen with aspirin $(150 \mathrm{mg} /$ day $)$ was reinitiated on postoperative day 1. Dabigatran $(2 \times 150 \mathrm{mg})$ was restarted on postoperative day 3 . On postoperative day 10 , the patient was discharged to a local rehabilitation facility.

\section{Discussion}

In contrast to vitamin $\mathrm{K}$ antagonists, dabigatran is reported to have a shorter half-life and thus narrower therapeutic window. In patients with normal renal function, the restoration of hemostasis is expected within 12-24 h after last dose intake [10]. Surgery or intervention should ideally be deferred, until $24 \mathrm{~h}$ after the last dose [10]. However, the real-life clinical practice shows that there are many situations, where reversal of dabigatran is required immediately. RE-VERSE AD trial demonstrated that idarucizumab is efficacious in dabigatran reversal [5]. Of note, in the REVERSE AD trial, in each case dabigatran and idarucizumab plasma levels were measured to assess the dabigatran reversal effect $[5,6]$.

The American Heart Association Scientific Statement from 2017 suggests for major bleeding in the event of dabigatran intake in emergency cases: compression when possible, supportive measures, and upfront idarucizumab [11]. Following the RE-VERSE AD trial, also in real-life cases

Table 1 Laboratory findings in patient with ACS and receiving dabigatran treatment with continuous heparin infusion

\begin{tabular}{|c|c|c|c|c|c|}
\hline & \multicolumn{5}{|l|}{ Measurement } \\
\hline & I (17:30) & II (18:20) & III (21:40) & IV (22:30) & V (24:00) \\
\hline Time period & Baseline & $50 \mathrm{~min}$ & $4 \mathrm{~h} 10 \mathrm{~min}$ & $5 \mathrm{~h} 00 \mathrm{~min}$ & $6 \mathrm{~h} 30 \mathrm{~min}$ \\
\hline Patient clinical status & $\begin{array}{l}\text { Admission to the } \\
\text { hospital, continuous } \\
\text { heparin infusion }\end{array}$ & $\begin{array}{l}\text { Preoperative depart- } \\
\text { ment, continuous } \\
\text { heparin infusion }\end{array}$ & $\begin{array}{l}\text { Just before surgery, } \\
\text { directly before idaru- } \\
\text { cizumab administra- } \\
\text { tion }\end{array}$ & $\begin{array}{l}\text { Cardiac surgery- CPB, } \\
\text { full dose heparin } \\
\text { therapy }\end{array}$ & $\begin{array}{l}\text { After } \mathrm{CPB} \text {, heparin } \\
\text { reversal using } \\
\text { protamine }\end{array}$ \\
\hline TT (s) [16.0-21.0] & 81.3 & $>150$ & 25.2 & $>150$ & 25.5 \\
\hline RT (s) [16.0-22.0] & 14.2 & 14 & 13.2 & 13 & 14.2 \\
\hline APTT (s) [25.9-36.6] & 151.6 & $>300$ & 57.1 & $>300$ & 48.3 \\
\hline PT (s) [10.4-13.0] & 15.3 & $>170$ & 14.4 & $>170$ & 17.6 \\
\hline $\begin{array}{l}\text { DABIGATRAN level } \\
(\mathrm{ng} / \mathrm{mL})\end{array}$ & 37 & ND & 33 & ND & 57 \\
\hline
\end{tabular}

$C P B$ Cardio-pulmonary bypass, $N D$ not done, $P T$ prothrombin time, $R T$ reptilase time, $A P T T$ activated partial thromboplastin time, $T T$ thrombin time 
dabigatran laboratory monitoring is performed before idarucizumab administration $[8,12,13]$.

However, in expert opinions, in life-threatening situations, when the last dose of dabigatran was intake $<12 \mathrm{~h}$ or there is uncertainty about the timing of last ingestion, it may be necessary to consider idarucizumab before the dabigatran level the results are known $[12,14]$. Still, there are no specific recommendations for dabigatran level monitoring after idarucizumab administration.

Our patient, who was taking dabigatran for VTE prophylaxis, required a life-saving CABG, and in this specific clinical scenario the continuous preoperative infusion of UFH was mandatory [15]. Both anticoagulants (dabigatran and heparin) inhibit the same level of coagulation cascade: dabigatran is a direct thrombin inhibitor, while heparin inhibits thrombin indirectly [16]. Therefore, because dabigatran and heparin have similar effects on thrombin, the coagulation tests used were clinically not useful for decision making.

The HTI method is based on the measurement of the diluted tested plasma clotting time after addition of the constant amount of human thrombin. Prolonged clotting times are associated with higher dabigatran concentrations. However, the HTI assay does not contain any heparin inhibitors, which is why heparin (or other thrombin inhibitors) present in the tested sample may interfere with the assay, and prolong the clotting time, producing falsely high plasma concentrations of dabigatran.

Normal reptilase time, and at the same time prolonged thrombin time, indicate that heparin is present in all tested samples. Thus, one might speculate that the dabigatran concentrations in samples I, III and V are falsely increased, however it is difficult to estimate how much. The thrombin time, prothrombin time and APTT measurement above the normal reference range in samples II and IV suggest that these samples contained heparin at very high concentrations. It was impossible to measure the concentration of dabigatran in these samples using the HTI.

Fast but reliable measurement of dabigatran concentrations in patients concomitantly receiving heparin is a challenge. The gold standard in accurate dabigatran concentrations measurement is liquid chromatography/tandem mass spectrometry (LC-MS/MS) [17], however, the availability of this method is limited, especially in the emergency setting. The HTI belongs to the group of commercially available "specific coagulation tests", which is favorable to LC-MS/ MS in some aspects, though susceptible to interference by heparin [18].

The new commercially available test for dabigatran quantification irrespectively of heparin intake is the chromogenic Innovance ${ }^{\circledR}$ DTI Assay (Siemens Healthcare Diagnostics Products GmbH, Marburg, Germany). According to the manufacturer, dabigatran measurement assays are not influenced by heparin concentrations of 8 and $15 \mathrm{IU} / \mathrm{mL}$, respectively. Another test based on diluted thrombin time Hemosil Direct Thrombin Inhibitor (Instrumentation Laboratory) is insensitive to UFH up to $2.2 \mathrm{IU} /$ $\mathrm{mL}$. In any case, care must be taken during sampling, to avoid additional contamination of test tubes with heparin.

Our case showed, that there are emergency situations, where laboratory measurement of dabigatran level may not be clinically useful because of drugs interactions that mask the anticoagulant effect of dabigatran. In such cases, HTI assay may be unrevealing. In life-threatening situations, when urgent surgery/procedure cannot be delayed, and if the patient received dabigatran within $<12 \mathrm{~h}$ (or when the timing of last dose intake is uncertain), idarucizumab should be administered without dabigatran level monitoring.

There is also a question why we observed an excessive postoperative bleeding despite idarucizumab administration. In previous cases the observed bleeding was moderate, however it might be speculated that the longer procedural time was a reason to transfuse the patient intraoperatively, while in the current case, with shorter procedural time, the transfusions followed in the intensive care unit [5]. Furthermore, there is evidence that plasma dabigatran levels may increase by up to $96 \%$ of the baseline value after successful initial neutralization by idarucizumab due to redistribution, and another idarucizumab dose is required [12]. Because of nondiagnostic measurement, we cannot exclude this phenomenon in our patient.

In conclusion, we report that dabigatran level monitoring may not always be feasible in patients requiring idarucizumab before an emergency cardiac surgery if UFH infusion is started. In our case, due to common affinity of dabigatran and heparin to thrombin, objective measurement of dabigatran could not be performed with the available test. We conclude that in a patient with any suspicion of recent dabigatran intake, in whom the drug level cannot be measured and the surgery deferred, idarucizumab should be administered in any case. Heparin insensitive dabigatran measurements should be preferred in cardiac surgery centers.

Acknowledgements The authors would like to thank Prof. Anetta Undas, $\mathrm{MD}$, PhD, for her valuable comments.

Author contribution RL and JK conceived and wrote the manuscript. $\mathrm{KB}$, discussed this letter to the editor. TG was involved in data analysis, especially in implementing laboratory aspects. PM performed critical revision of the manuscript.

\section{Compliance with ethical standards}

Conflict of interest The authors declare that they have no conflicts of interest.

Ethical approval All procedures performed in studies involving human participants were in accordance with the ethical standards of the insti- 
tutional and/or national research committee and with the 1964 Helsinki declaration and its later amendments or comparable ethical standards.

Open Access This article is distributed under the terms of the Creative Commons Attribution 4.0 International License (http://creativecommons.org/licenses/by/4.0/), which permits unrestricted use, distribution, and reproduction in any medium, provided you give appropriate credit to the original author(s) and the source, provide a link to the Creative Commons license, and indicate if changes were made.

\section{References}

1. Ruff CT, Giugliano RP, Braunwald E, Hoffman EB, Deenadayalu N, Ezekowitz MD, Camm AJ, Weitz JI, Lewis BS, Parkhomenko A, Yamashita T, Antman EM (2014) Comparison of the efficacy and safety of new oral anticoagulants with warfarin in patients with atrial fibrillation: a meta-analysis of randomised trials. Lancet 383(9921):955-962. https://doi.org/10.1016/ s0140-6736(13)62343-0

2. Caldeira D, Rodrigues FB, Barra M, Santos AT, de Abreu D, Goncalves N, Pinto FJ, Ferreira JJ, Costa J (2015) Non-vitamin K antagonist oral anticoagulants and major bleeding-related fatality in patients with atrial fibrillation and venous thromboembolism: a systematic review and meta-analysis. Heart 101(15):1204-1211. https://doi.org/10.1136/heartjnl-2015-307489

3. Di Nisio M, van Es N, Buller HR (2016) Deep vein thrombosis and pulmonary embolism. Lancet 388(10063):3060-3073. https:// doi.org/10.1016/s0140-6736(16)30514-1

4. Douketis JD, Healey JS, Brueckmann M, Fraessdorf M, Spyropoulos AC, Wallentin L, Oldgren J, Reilly P, Ezekowitz MD, Connolly SJ, Yusuf S, Eikelboom JW (2016) Urgent surgery or procedures in patients taking dabigatran or warfarin: analysis of perioperative outcomes from the RE-LY trial. Thromb Res 139:77-81. https://doi.org/10.1016/j.thromres.2016.01.004

5. Pollack CV Jr, Reilly PA, Eikelboom J, Glund S, Verhamme P, Bernstein RA, Dubiel R, Huisman MV, Hylek EM, Kamphuisen PW, Kreuzer J, Levy JH, Sellke FW, Stangier J, Steiner T, Wang B, Kam CW, Weitz JI (2015) Idarucizumab for dabigatran reversal. N Engl J Med 373(6):511-520. https://doi.org/10.1056/ NEJMoa1502000

6. Pollack CV Jr, Reilly PA, van Ryn J, Eikelboom JW, Glund S, Bernstein RA, Dubiel R, Huisman MV, Hylek EM, Kam CW, Kamphuisen PW, Kreuzer J, Levy JH, Royle G, Sellke FW, Stangier J, Steiner T, Verhamme P, Wang B, Young L, Weitz JI (2017) Idarucizumab for dabigatran reversal-full cohort analysis. N Engl J Med 377(5):431-441. https://doi.org/10.1056/ NEJMoa1707278

7. Heidbuchel H, Verhamme P, Alings M, Antz M, Diener HC, Hacke W, Oldgren J, Sinnaeve P, Camm AJ, Kirchhof P (2016) Updated European Heart Rhythm Association practical guide on the use of non-vitamin-K antagonist anticoagulants in patients with non-valvular atrial fibrillation: executive summary. Eur Heart J. https://doi.org/10.1093/eurheartj/ehw058
8. Mazur P, Darocha T, Filip G, Grudzien G, Drwila R, Kapelak B (2016) Idarucizumab for dabigatran reversal in patients with atrial fibrillation undergoing emergency surgery for acute aortic syndrome. Pol Arch Med Wewn 126(7-8):579-581. https://doi. org/10.20452/pamw.3470

9. Dyke C, Aronson S, Dietrich W, Hofmann A, Karkouti K, Levi M, Murphy GJ, Sellke FW, Shore-Lesserson L, von Heymann C, Ranucci M (2014) Universal definition of perioperative bleeding in adult cardiac surgery. J Thorac Cardiovasc Surg 147(5):14581463. https://doi.org/10.1016/j.jtcvs.2013.10.070

10. Heidbuchel H, Verhamme P, Alings M, Antz M, Diener H-C, Hacke W, Oldgren J, Sinnaeve P, Camm AJ, Kirchhof P (2015) Updated European Heart Rhythm Association Practical Guide on the use of non-vitamin $\mathrm{K}$ antagonist anticoagulants in patients with non-valvular atrial fibrillation. Europace 17(10):1467-1507

11. Raval AN, Cigarroa JE, Chung MK, Diaz-Sandoval LJ, Diercks D, Piccini JP, Jung HS, Washam JB, Welch BG, Zazulia AR, Collins SP (2017) Management of patients on non-vitamin K antagonist oral anticoagulants in the acute care and periprocedural setting: a scientific statement from the American Heart Association. Circulation 135(10):e604-e633. https://doi.org/10.1161/ cir.0000000000000477

12. Simon A, Domanovits H, Ay C, Sengolge G, Lewy JH, Spiel AO (2017) Recommended dose of Idarucizumab may not always be sufficient for sustained reversal of dabigatran. J Thromb Haemost. https://doi.org/10.1111/jth.13706

13. Vosko MR, Bocksrucker C, Drwila R, Dulicek P, Hauer T, Mutzenbach J, Schlimp CJ, Spinler D, Wolf T, Zugwitz D (2017) Real-life experience with the specific reversal agent idarucizumab for the management of emergency situations in dabigatran-treated patients: a series of 11 cases. J Thromb Thrombolysis 43(3):306317. https://doi.org/10.1007/s11239-017-1476-2

14. Vanassche T, Greinacher A, Verhamme P (2016) Reversal of dabigatran by idarucizumab: when and how? Expert Rev Hematol 9(6):519-528. https://doi.org/10.1080/17474086.2016.1184569

15. Amsterdam EA, Wenger NK, Brindis RG, Casey DE Jr, Ganiats TG, Holmes DR Jr, Jaffe AS, Jneid H, Kelly RF, Kontos MC, Levine GN, Liebson PR, Mukherjee D, Peterson ED, Sabatine MS, Smalling RW, Zieman SJ (2014) 2014 AHA/ACC guideline for the management of patients with non-ST-elevation acute coronary syndromes: executive summary: a report of the American College of Cardiology/American Heart Association Task Force on Practice Guidelines. Circulation 130(25):2354-2394. https:// doi.org/10.1161/cir.0000000000000133

16. Bijak M, Bobrowski M (2010) The importance of thrombin inhibitors in the antithrombotic pharmacotherapy. Postępy Nauk Medycznych 10:819-825

17. Samuelson BT, Cuker A (2017) Measurement and reversal of the direct oral anticoagulants. Blood Rev 31(1):77-84. https://doi. org/10.1016/j.blre.2016.08.006

18. Cuker A (2016) Laboratory measurement of the non-vitamin $\mathrm{K}$ antagonist oral anticoagulants: selecting the optimal assay based on drug, assay availability, and clinical indication. J Thromb Thrombolysis 41(2):241-247. https://doi.org/10.1007/ s11239-015-1282-7 